\title{
Does Financial Development Affect the Economic Growth Gains from Trade Openness?
}

\section{A panel data analysis}

\section{Imen Mohamed Sghaier}

\section{Summary}

This article examines the relationship between trade openness, financial development and economic growth on a panel of four North African countries (Tunisia, Morocco, Algeria and Egypt), over a 5-year period from 1998 to 2017. Using dynamic panel data model estimated by means of the Generalized Method of Moments (GMM), we found that trade openness is positively related to economic growth. We also found that trade openness appears to be working as a complement to financial development and, moreover, that the effect of trade openness is more pronounced in the presence of the financial development variable. The findings suggest that trade openness and financial development are important elements in determining economic growth in these countries. Therefore, the policy-makers should continue to patronize the development of their financial sector and to allow more trade openness in order to achieve a high and sustainable economic growth.

Keywords: Trade openness, Financial development, Economic growth, Panel data analysis

JEL: F13, O16, F43, C23

\section{Introduction}

$\Lambda$ mong the macroeconomic variables Athat the empirical literature on growth has identified as being closely associated with the growth of real GDP across countries are the level of financial development and the degree of trade openness (Beck, 2002). Financial constraints can prevent firms, mainly in developing countries, from taking full advantage of technology transfer (Aghion et al. 2005). Developing countries with a less developed financial system tend to experience lower per capita GDP growth. This phenomenon can be interpreted as evidence that the developing countries are trapped in a vicious cycle. Indeed, an underdeveloped financial system prevents a poor economy from taking full advantage of financial services to promote economic growth on

\footnotetext{
Assistant Professor, Department of Economics, Higher Institute of Business Administration, University of Sfax, Tunisia.
} 


\section{Articles}

the one hand, and slow economic growth is not able to generate sufficient demand for financial services necessary for the financial development on the other (Fung, 2009). Countries with better-developed financial systems tend to grow faster, particularly, countries with (i) large, privately owned banks that extend loans to private firms and (ii) liquid stock exchanges tend to grow faster than countries with corresponding lower levels of financial development (Levine, 2005).

Moreover, the endogenous growth theory as articulated by Romer (1990) and Grossman and Helpman (1991) and others also highlighted the importance of financial system development in the process of economic growth by improving efficiency and resource allocation, capital accumulation and technological progress (see King and Levine, 1993; Beck et al. 2000). Furthermore, Blackburn and Hung (1998) also showed that both financial development and trade liberalization jointly promote economic growth by reducing redundant information in search results and expanding markets for new products. What is important, however, is whether these potential benefits of financial development and trade openness are gained by North African countries.

The main potential contributions of the paper are threefold. First, we believe that this study is the first to analyze the link between trade openness, financial development and economic growth in the North Africa region. Second, the empirical study involves regressing economic growth of trade openness, financial development, interactions between these two variables, and other growth factors suggested in the literature. However, the trade openness and financial development variables are likely to be endogenous, possibly because of feedback from economic growth to trade openness and financial development. Therefore, this study uses generalized method of moments (GMM) estimation to deal with endogeneity and simultaneity bias. Lastly, in terms of policy implications, the results of this study will guide policy makers in designing policies aimed at a well-developed financial system which is potent in ensuring the effectiveness of trade openness and promoting economic growth.

The purpose of the present paper is to examine the role of financial development in mediating the impact of trade openness on economic growth of a group of four North African countries, namely Tunisia, Morocco, Algeria, and Egypt over a 5-year period from 1998 to 2017. Our dynamic panel regression analyses show that trade openness has a positive and significant impact on economic growth in North African countries. This study also provides direct evidence of complementarities between trade openness and financial development. From a policy perspective, efforts aimed at reforming domestic financial system may have important repercussions for each sector and finally trade if the level of finance is a critical driver of economies' comparative advantage.

The remainder of the paper is organized as follows. Section 2 provides a detailed literature review. Section 3 describes the used data and the empirical methodology. Section 4 presents the empirical results. Section 5 presents the concluding remarks and policy implications.

\section{Trade openness, financial} development and economic growth: An overview

\subsection{Trade openness and economic growth}

The recent endogenous growth theories direct attention to the implications of trade openness on economic growth. According 


\section{Articles}

to Rivera-Batiz and Romer (1991), trade openness offers four different opportunities that may lead to economic growth:

i) Communication effect: Trade openness offers new job opportunities for communicating with foreign counterparts, which in turn promote the transfer of technology.

ii) Duplication effect: In the absence of trade openness, some ideas and technologies are duplicated in many countries. Openness promotes local companies to invent new technologies and, consequently, avoid duplication of research activities.

iii) Integration effect: International trade immediately boosts the size of the market available for each company. Supposing intermediate goods as well as final goods are traded between countries, larger market size of the R\&D sector increases R\&D activity and, therefore, economic growth.

iv) Allocation effect: The theory of comparative advantage states that trade openness allows countries to specialize in production of goods and services that offer them economies of scale.

In other words, trade openness allows countries to provide a maximum output with the given input resources - which is a movement in the direction of conservation of environmental sustainability.

Consistent with previous studies, they affirmed the positive link between trade openness and economic growth. For example, Barro and Sala-i-Martin (1997) argued that in the long run, trade openness may contribute to economic growth by disseminating technological knowledge embodied in imported goods and from the spillover effects of foreign direct investment, i.e. financial openness, from the collaboration with the external sources of innovations (Almeida and Fernandes, 2008), increasing market size to
Does Financial Development Affect

the Economic Growth Gains from Trade Openness?

get maximum results from trade liberalization by rising returns to scale and product differentiation (Bond et al. 2005). Rajan and Zingales (2003) stated that trade openness pushes the governments to launch a series of policy reforms to face foreign competition.

Santos-Paulino and Thirlwall (2004) showed that liberalization in the case of developing countries promotes exports but even more so imports, producing a deterioration of the overall trade and payment balances in these countries. Rassekh (2007) concluded that trade openness benefits the developing countries (i.e. low-income countries) more than the developed ones, for a sample of 150 countries. Economidou and Murshid, (2008) used data from 12 OECD countries to examine whether trade increases the productivity of manufacturing industries. The results of their study showed a positive effect of trade on the productivity growth of the manufacturing industry.

Chang et al., (2009) concluded that trade openness is positively related to economic growth in 82 countries. They also showed that this association can be improved significantly, particularly for developing countries, if trade reforms are combined with financial development, public infrastructure, and governance reforms. Similarly, Dufrenot et al. (2010) noted that developing countries are obtaining maximum results from trade openness as compared to developed economies.

Kim et al. (2012) provided robust empirical evidence that trade openness stimulates economic growth in high-income, lowinflation, and non-agricultural countries. For a group of 46 countries, Huang and Chang (2014) argued that the economic growth effect of trade openness depends on the extent of stock market development. Trade promotes economic growth only when the country attains a basic level of stock market 


\section{Articles}

development. Zahonogo (2016) found that trade openness may impact economic growth favorably in 42 sub-Saharan Africa countries (SSA). He suggested that SSA countries must have more effective trade openness, particularly by productively controlling import levels, in order to enhance their economic growth through international trade. Sakyi et al. (2017) investigated the effects of trade and trade facilitation on economic growth in Africa. They argued that trade facilitation serves as an essential channel through which trade affects economic growth.

Stanojević and Veličković (2019) examined empirically the effects of European Union accession and trade openness on economic growth of the most recent 13 European Union members (Cyprus, Czech Republic, Estonia, Hungary, Lithuania, Latvia, Malta, Poland, Slovenia, Slovak Republic, Romania, Bulgaria and Croatia). They concluded that country's openness to international trade contributes to the enhancement of its economic growth. Redmond and Ali Nasir (2020) investigated the impacts of trade openness and institutional quality on two proxies for economic development - economic growth and a human development index. The impact is evaluated in aggregate as well as the countries' level of development in three groups - Lower-middle, Upper-middle and High Income Countries. They found that trade openness' positive effect exceeds that of institutional quality. More recently, Kpomblekou and Wonyra (2020) argued that international trade spreads widely and positively in the West African Economic and Monetary Union. There are thus inter-country economic gains in exchange in the union. They concluded that the promotion of economic cooperation and the policy of free movement of goods and services and individuals in the union must thus remain very favorable to the trade and economic growth of the countries.

\subsection{Financial development and trade openness}

There are many ways in which financial development could influence trade openness. First, industries which are more dependent on external finance grow faster in countries with greater financial development. As a result, those economies with under-developed financial system have lower export share in industries with higher external finance dependence. Thus, the level of financial system development has an impact on trade patterns across countries (Rajan and Zingales, 1998). For instance, Beck (2002) noted that countries with more developed financial systems have a comparative advantage in manufacturing, as the financing of the considerable fixed costs faced by this system is cheaper in such countries. Second, financial development, insofar as it reduces the distortive effects of financial frictions, can positively involve productivity and tilts the structure of production towards capitalintensive sectors (Buera et al. 2011). Third, as trade openness augments a country's exposure to world market fluctuations, a well-developed financial system functions as a protection mechanism against external risks, helps greater trade openness (Kim et al. 2010).

The empirical findings confirm the existence of a finance-trade nexus, although the subject has not been studied exhaustively. Svaleryd and Vlachos (2002) viewed the financial sector as a factor of production. A country relatively well endowed with wellfunctioning financial institutions should tend to specialize in sectors relatively intensive in the use of financial services. As a result, countries with well-functioning financial systems tend to specialize in industries highly dependent on external financing. Among OECD countries, Svaleryd and Vlachos (2005) found a strong causal effect of the financial 


\section{Articles}

sector on industrial specialization. They concluded that a well-developed economic sector is extremely beneficial to the private sector and it encourages businesses with the exploitation of external funding so that industries can be overwhelmed by restrictions of liquidity. Hur et al. (2006) investigated the relationship between financial development, asset tangibility, and international trade. Using industry-level data on firms' dependence on external finance and firms' asset tangibility for 27 industries in 42 countries, they found that countries with higher levels of financial development have higher export shares and trade balance in industries with more intangible assets.

Kim et al. (2010) investigated whether trade openness and financial development complement each other or are substitutes for 87 countries. They noted that longrun complementarity between financial development and trade openness coexists with short-run interchangeability between the two policy variables. But when splitting the data into OECD and non-OECD country groups, this finding can be observed only in non-OECD countries. For OECD countries, financial development has negligible effects on trade. Niroomand et al. (2014) studied the relationship between financial development and trade openness in 18 emerging economies. They showed that in the majority of these countries, either banking sector development or stock market development or both have had significant impact on trade openness, implying that a well-developed and well-functioning financial market creates more international trade opportunity for emerging economies.

The empirical evidence that looks into the link between trade openness and financial development for Africa is rather limited. In a study based on Kenya, Wolde-Rufael (2009) found that financial development causes both
Does Financial Development Affect

the Economic Growth Gains from Trade Openness?

imports and exports growth but the causality relationship was weak in the opposite direction. Susanto et al. (2011) showed that there is a positive impact of financial development on bilateral trade flows for the manufacturing sector, which enjoys a greater impact than the agricultural sector. The impacts differ across regions. In most cases, developing countries (Asia, Latin America, MENA and SSA) experience greater impacts of financial development on exports in both agriculture and manufacturing sectors than do advanced countries.

Sare et al. (2018) studied the impact of financial development on international trade in 46 African countries. They revealed differential effects of finance on trade. In particular, they noticed that private credit hampers trade while domestic credit significantly stimulates international trade flows. They concluded that there is a $U$-shaped relationship between private credit and trade measures. This implies that financial system development may be detrimental (helpful) to trade for countries with low (high) level of private credit. By relying on 46 countries in Africa, Sare (2019) used a sample splitting and threshold estimation approach which allows financeinternational trade to be mediated by the level of domestic financial system development. He found evidence of threshold effects for a number of the countries suggesting that the particular impact of financial development on international trade is threshold-specific given the various indicators of finance. He concluded that whether finance supports or limits international trade significantly depends on the realization of a certain threshold which is both country and indicator-specific. More recently, Zouri (2020) identified the determinants of synchronization of business cycles in ECOWAS, which is a key issue from the perspective of creating a single currency in 2020. He found that bilateral trade and 


\section{Articles}

financial integration are determinants of the synchronization of business cycles in the region, with the regional financial integration channel dominating the international one.

\subsection{Financial development and the trade openness - growth link}

Although a vast literature on the financial development is available, at either country level or cross country level, the interest is still growing by also introducing some other potential variables. For example, whether trade openness harms or stimulates the link of economic growth and financial development is another dimension of the literature. The relationship between financial development, trade openness and economic growth is one of the most important research topics in economic literature and has been extensively considered by many researchers. Jin (2000) argued that countries with more open trade and financial policies may grow faster than those with restricted trade and financial policies. Yanikkaya (2003) found strong evidence in support of the positive relationship between trade and growth through channels such as technology transfers, scale economies and comparative advantage. They concluded that Trade and Financial Liberalization policies aim to promote productivity by decreasing inefficiencies in investment.

Chang et al. (2009) concluded that institutional complementarity between financial and trade openness can be observed when focusing on GDP growth rather than productivity for 22 developed and 60 developing countries. In particular, they showed that increase in trade openness is associated with increases in real GDP per capita growth when the ratio of private credit to GDP is high. This evidence supports the view that the positive impact of trade openness reforms on economic growth can be improved by financial development.
Yilmazkuday (2011) confirmed that growth enhancing effect of finance depends on a number of factors such as trade openness. He found that trade openness strengthens the finance-growth link in low-income countries, but its effect is minimal in high-income countries. Peters and Schnitzer (2012) also argued that trade openness and financial development are complements. When trade between two countries is open, financial development is necessary for firms in both countries not only to benefit from new export opportunities, but also to face fiercer competition from imported products. If financial constraints are still tight and market segmentation is important in one of the two countries, neither productivity nor technological convergence will be viewed.

Another study that has examined the impact of trade openness on the financegrowth link is that of Herwartz and Walle (2014). Using annual data for 73 countries, they found that high levels of trade openness increase the growth-promoting role of nancial institutions. Polat et al. (2015) confirmed the existence of a feedback effect between trade openness and financial development that was observed in South Africa both in the short and long run. The findings of their study strongly support policies to promote financial system development in South Africa thus helping to encourage economic growth.

Pradhan et al. (2017) studied the linkages between banking sector depth, trade openness, and economic growth using a panel data set covering the ASEAN regional forum countries. They found a general longrun equilibrium relationship among trade openness, banking sector depth and economic growth as well as a short-run relationship between these variables. They recommended that governments of home countries should increase greater banking sector depth as well as promoted trade openness. Rani and Kumar (2018) examined the relationship 


\section{Articles}

between financial development, trade openness and economic growth of BRICS countries over the period between 1993 and 2015. They registered a long-run relationship among the variables. They found that financial development has positive effect on economic growth. Mohamed Sghaier (2018) also suggested that financial development is an essential determinant as well as a major contributor of economic growth for a group of four North African countries (Tunisia, Morocco, Algeria and Egypt).

Ramírez-Rondán et al. (2018) argued that financial system development could be a key enabler of the economic growth benefits of trade openness for a sample of 80 countries. They found that there is a financial development threshold in which trade openness has a positive and significant relationship with economic growth. Ehigiamusoe and Lean (2018) examined the trilateral relationship between financial development, trade openness and economic growth in Ghana, Nigeria and South Africa. They revealed a long-run causal relationship between financial development, trade openness and economic growth, thereby supporting finance- and trade-led growth hypotheses for these countries. They concluded that financial development and trade openness can be deployed to accelerate economic growth in all of the countries examined. More recently, Alagidede et al. (2020) observed the impact of trade and financial integration on structural transformation relying on data from 28 countries in SSA. They showed that, trade and financial integration significantly spur manufacturing and agricultural sector value additions. However, for the industrial sector, only financial integration robustly influences industrial growth with no effect on the service sector. They also recommended that trade
Does Financial Development Affect

the Economic Growth Gains from Trade Openness?

and financial integration are complementary to each other and do not operate independently to influence structural transformation in SSA.

This paper is inspired by similar considerations and attempts to test the complementarities between trade openness and financial development in the North African countries over the period 1998-2017.

\section{Data and Empirical Methodology}

\subsection{Data}

This paper considers a sample of four North African countries, namely Tunisia, Morocco, Algeria and Egypt. The choice of the selected countries for this study is primarily dictated by the availability of reliable data over the sample period. The panel covers the period 1998-2017, and is divided into five non-overlapping 5-year periods. ${ }^{1}$ The dependent variable is economic growth, measured as the growth rate of real GDP per capita at 2010 USD prices. Trade openness (TRADE) is represented by the ratio of the sum of exports and imports to GDP since the empirical growth literature has shown that openness to international trade is an important factor determining economic growth. The main variable of interest (trade openness) and the other control variables are obtained from the World Development Indicators database (World Bank, 2020).

We include a country's level of financial development as another regressor, because it helps saving and investment decisions. Financial markets also allow for risk diversification through the negotiation of financial instruments that facilitate identification of profitable investment projects and mobilize savings on them. Financial development (FD) is defined as the ratio of credit provided by the banking sector to

\footnotetext{
${ }^{1}$ Most panel studies on economic growth cycles are based on five-year averages as the time unit to eliminate the business cycle effect.
} 


\section{Articles}

GDP. This indicator measures how much intermediation is performed by the banking system, including lending to the public and the private sectors. Calderon and Liu (2003) found that a higher ratio of credit provided by the banking sector to the GDP shows more financial services and therefore, more efficient financial intermediation and greater contributions to overall economic growth.

The hypothesis that trade openness and other economic and institutional variables affect economic growth is tested by estimating dynamic panel data model for GDP per capita growth over consecutive, non-overlapping, 5-year periods, from 1998 to 2017 . $^{2}$ Specifically we consider the most used variables in the empirical economic growth theory defined as follows (all except initial GDP per capita are averaged over each 5-year period):

- Initial GDP per capita (log): log of real GDP per capita lagged by one 5-year period. The link between initial per capita GDP and growth rates is a vital implication of the neoclassical growth theory; that is, an economy's growth performance depends on its initial position. This literature indicates that, ceteris paribus, backward countries with a low capitaloutput ratio may grow faster than rich countries due to the diminishing return to factors of production. A negative coefficient is expected;

- Private investment ( $\%$ GDP) is viewed as a direct proxy of contribution to capital accumulation, as well as an indicator of efforts to develop basic economic infrastructure. It is defined as the ratio of gross fixed capital formation to GDP. A positive coefficient is estimated, as greater investment shares have been shown to be positively associated with economic growth (Mankiw et al. 1992);

- Human capital is a key determinant of technology adoption as permitted by trade openness. The effect of human capital is measured by primary school enrollment. Greater enrollment ratios lead to greater human capital, which should be positively associated with economic growth (Benhabib and Spiegel, 2005). A positive coefficient is expected.

In order to account for the effects of macroeconomic stability on economic growth, two additional variables will be added to the model ${ }^{3}$ :

- Inflation rate measured as the annual percentage change in the consumption price index. ${ }^{4}$ A negative coefficient is expected, as high inflation has been shown to affect economic growth negatively (Elder, 2004);

- Government spending defined as the ratio of central government expenditures to GDP. Excessive government spending is expected to crowd out investment in the private sector and be harmful to economic growth (Nguyen and Trinh, 2018). Thus, a negative coefficient is expected.

The extended model will also include the following institutional variable ${ }^{5}$ :

\footnotetext{
2 The periods are: 1998-2002, 2003-2007, 2008-2012, and 2013-2017.

${ }^{3}$ Following Levine et al. (2000), we include the inflation rate and the government size to proxy for macroeconomic stability in a growth regression.

${ }^{4}$ In order to solve the problem of heteroscedasticity resulting from the high variability of inflation rates, Inflation was defined as $\log (1+\operatorname{lnf} / 100)$.

${ }^{5}$ There is an extensive literature that looks at the role of institutions on economic growth. See, among others, Acemoglu et al. (2001), Glaeser et al. (2004) and De Haan (2007).
} 


\section{Articles}

- The economic freedom of the World index from the Fraser Institute is used to measure the freedom of economic activities in a country. Higher indices are related to smaller governments (Area 1), stronger legal structure and security of property rights (Area 2), access to sound money (Area 3), greater freedom to trade internationally (Area 4), and more flexible regulations of credit, labor, and business (Area 5). The comprehensive area scores are all on a scale from zero to 10 , with zero being the least and 10 being the most free. The greater the economic freedom the more it enhances economic growth (Azman-Saini et al. 2010). Thus, a positive coefficient is expected. The data are obtained from Gwartney et al. (2019).

\subsection{Empirical methodology}

The purpose of our empirical analysis is to examine if financial development plays an important role in influencing the effects of trade openness on economic growth in North Africa. To this end, we employ a specification that is broadly similar to others (e.g., Gries et al. 2009; Herwartz and Walle, 2014). We consider the following model:

$$
\begin{array}{r}
y_{i, t}=\alpha y_{i, t-1}+\beta_{1} T R A D E_{i, t}+\beta_{2} F D_{i, t}+ \\
\beta_{3} X_{i, t}+\mu_{t}+\eta_{i}+\varepsilon_{i, t}
\end{array}
$$

Eq. (1) can also be alternatively written with the growth rate as a dependent variable as:

$$
\begin{array}{r}
\text { Growth }_{i, t}=y_{i, t}-y_{i, t-1}=(\alpha-1) y_{i, t-1}+ \\
\beta_{1} \operatorname{TRADE}_{i, t}+\beta_{2} F D_{i, t}+\beta_{3} X_{i, t}+ \\
\mu_{t}+\eta_{i}+\varepsilon_{i, t}
\end{array}
$$

The subscript " $t$ " represents one of these 5-year periods, whereas $i$ represents the country, $y$ is the logarithm of the real GDP per capita, TRADE is trade openness, $F D$ is the financial development variable and $X$ is the matrix of control variables, $\mu_{t}$ is a time
Does Financial Development Affect

the Economic Growth Gains from Trade Openness?

specific effect, $\eta_{i}$ is an unobserved countryspecific fixed effect and $\varepsilon_{i, t}$ is the error term. Eq. (2) forms the basis for our estimation. $(\alpha-1)$ is the convergence coefficient.

While TRADE has the potential to affect economic activity through a host of channels, in a second set of regressions, we examine one specific link between TRADE and economic growth, specifically the one working through $F D$. The hypothesis we would like to test is whether the level of $F D$ in the host country affects TRADE on economic growth. To this end, we add an interaction term constructed as the product of TRADE and the FD (i.e., $T R A D E^{*} F D$ ) to Eq. (2) as an additional explanatory variable, apart from the standard variables used in the economic growth equation. To ensure that the interaction term does not proxy for TRADE or the level of $F D$, both of the latter variables were included in the regression independently. If the coefficient on the interaction term is positive and significant, it implies that the marginal effect of TRADE on economic growth depends on the level of $F D$.

The regression to be estimated is the following:

Growth $_{i, t}=(\alpha-1) y_{i, t-1}+\beta_{1}$ TRADE $_{i, t}+$

$$
\begin{gathered}
\beta_{2} F D_{i, t}+\beta_{3}\left(\text { TRADE } E_{i, t} \cdot F D_{i, t}\right)+(3) \\
\beta_{4} X_{i, t}+\mu_{t}+\eta_{i}+\varepsilon_{i, t}
\end{gathered}
$$

This paper applies the GMM panel estimator developed by Arellano and Bond (1991), Arellano and Bover (1995), and Blundell and Bond (1998). There are two main reasons for choosing this estimator. The first is to control for country-specific effects, which cannot be done with country-specific dummies due to the dynamic structure of the regression equation. Second, is to control for a simultaneity problem caused by the possibility that some of the explanatory variables may be endogenous with growth or other dependent variables. 


\section{Articles}

We analyze this endogeneity by using a two-step system GMM for the estimation of dynamic unbalanced panel data. In the case of a strong endogeneity, the twostage least squares (2SLS) method can be used. However, Lin and Lee (2010) showed that estimations provided by 2SLS are often weak in the presence of heteroscedasticity. In this context, the GMM is more effective (Lee, 2007). Precisely, system GMM estimators are well-known to treat situations in which explanatory variables are not strictly exogenous. Therefore, the traditional fixed effect estimator is incoherent because the mean of the lagged dependent variable is correlated with the idiosyncratic error term. As mention by Nickell (1981), this problem becomes particularly interesting in dynamic panel data models with relatively few time periods. A particular solution has been established by Arellano and Bond (1991), Arellano and Bover (1995) (and extended by Blundell and Bond (1998)) who argued that the system GMM estimators will reduce the bias associated with the fixed effects in short panels and resolve the problem of endogeneity in dynamic panel data. It is worth mentioning that a two-step system GMM estimator is asymptotically more efficient than a one-step estimator (based on a sub-optimal weighting matrix). However, the former might produce a bias of uncorrected standard errors when the instrument count is high, implying that the number of instruments is less than the number of the cross-sections, which was highlighted by Roodman (2006).

Following suggestions by Roodman (2006), the validity of the instruments implemented in GMM is generally verified by using the Hansen and the Arellano-Bond's AR(2) tests for the estimation of autocorrelation. It is also worth noting that the asymptotic standard errors of the two-step GMM estimators can be reduced through decomposition into small samples (Windmeijer, 2005). As noted in Windmeijer (2005), a Monte Carlo simulation shows that the conventional asymptotic variance estimate of two-step GMM estimators is a good estimate of the variance of GMM estimators using all the true values of the parameters to calculate the efficient weight matrix. In other words, the estimated corrected variance of the two-step GMM estimators achieves more accurate inference results. The two-step system GMM estimators are a good estimation tested in many existing research (Baltagi, 2008) and that is why we used it in this study.

\section{Empirical results}

The empirical results are presented in Table 1. Column (1) reports a preliminary analysis on the effects of TRADE and FD on economic growth. Column (2) presents the coefficient estimates obtained from the baseline specification, which used an interaction term constructed as a product of TRADE and FD. 
Table 1: The growth effect of trade openness and financial development

\begin{tabular}{|c|c|c|}
\hline Variable & (1) & (2) \\
\hline Initial GDP per capita & $\begin{array}{r}-0.07513^{\star * *} \\
(-4.1359)\end{array}$ & $\begin{array}{r}-0.07465^{\star * *} \\
(-4.09)\end{array}$ \\
\hline Trade openness & $\begin{array}{r}0.0289^{* *} \\
(2,079)\end{array}$ & $\begin{array}{r}0.0383^{\star *} \\
(2.32)\end{array}$ \\
\hline Financial Development & $\begin{array}{r}0.0294^{*} \\
(1.785)\end{array}$ & $\begin{array}{r}0.0298^{*} \\
(1.83)\end{array}$ \\
\hline Trade openness ${ }^{\star}$ Financial Development & & $\begin{array}{r}0.0046^{\star} \\
(1.81)\end{array}$ \\
\hline Private Investment & $\begin{array}{r}0.0325^{\star} \\
(2.017)\end{array}$ & $\begin{array}{r}0.0357^{* *} \\
(2.21)\end{array}$ \\
\hline Human capital & $\begin{array}{r}0.0066^{\star * \star} \\
(2.73)\end{array}$ & $\begin{array}{r}0.0071^{* * *} \\
(2.81)\end{array}$ \\
\hline Inflation & $\begin{array}{r}-0.01^{* * *} \\
(-2.871)\end{array}$ & $\begin{array}{r}-0.0112^{* * \star} \\
(-2948)\end{array}$ \\
\hline Government Spending & $\begin{array}{l}-0.0025 \\
(-0.125)\end{array}$ & $\begin{array}{r}-0.0149 \\
(-0.57)\end{array}$ \\
\hline Index of Economic Freedom & $\begin{array}{r}0.0018^{\star} \\
(1.958)\end{array}$ & $\begin{array}{r}0.0019^{*} \\
(2.11)\end{array}$ \\
\hline Constant & $\begin{array}{r}0.204 \\
(0.909)\end{array}$ & $\begin{array}{r}0.0813 \\
(0.17)\end{array}$ \\
\hline R-Squared & 0.47 & 0.54 \\
\hline$A R(2)$ test ( $p$-value) & 0.654 & 0.578 \\
\hline Sargan test ( $p$-value) & 0.741 & 0.62 \\
\hline
\end{tabular}

Notes: The dependent variable is the growth rate of real GDP per capita. System GMM estimations in dynamic panel data models. Sample period 1998-2017. AR(2) is a test of second order residual serial correlation. J-test is the Hansen over identification test. T-statistics are in parenthesis. ${ }^{*},{ }^{* *}$, and ${ }^{* * *}$ indicate statistical significance at $10 \%, 5 \%$ and $1 \%$ levels, respectively.

The results in Column (1) clearly confirm the assumption that trade openness has a positive and significant effect on economic growth. Indeed, trade openness provides these countries with access to the investment and intermediate goods that are vital to their development and the transfer of foreign technology, but such countries should productively reduce the import of consumption goods, by creating an environment that is conducive to efficiently producing domestically competing products in which there is dynamic comparative advantage. These findings suggest that the openness of North African countries to international trade should be linked with economic growth, which is in line with other empirical works (Yanikkaya, 2003; Chang et al. 2009; and Chang and Mendy, 2012). Meanwhile, the financial development coefficient carries a positive sign and is statistically significant at conventional levels, confirming a longrun positive relationship between financial development and economic growth. This positive impact is in line with much of the empirical finance and economic literature (see Levine, 2005, for a broad survey). These results recommend that policy makers place special emphasis on implementing policies that result in the deepening of financial markets, including institutional and legal measures to strengthen creditor and investor rights and 


\section{Articles}

contract enforcement. Thus, by promoting the development of a country's financial system, economic growth will be accelerated. Notice that the coefficients of the core variables considered in the equation enter the regression equation with the correct sign and are rated as significant at the $10 \%$ significance level or better. Additionally, the estimated regression passed both specification tests. The null hypothesis of no second-order serial correlation cannot be rejected at the $5 \%$ level. The regression is not plagued by simultaneity bias as the orthogonality conditions cannot be rejected at the 5 percent level, as indicated by Hansen's test. This suggests that the equation is adequately specified and the instruments employed in the analysis are valid.

Next, Column (2) shows the regression results based on interaction specification using an interaction term between trade openness and financial development (TRADE*FD). In this specification, we first test whether the trade-growth relationship changes with the development of the financial sector. If the term is positive and significant, this implies that the impact of trade openness on economic growth increases with financial development. The first thing to note is that the coefficient of the interaction term is positive and significant at $10 \%$ level. This result implies that a greater openness to trade is linked with strong economic growth when the financial system is more developed. In other words, greater access to credit may allow the exportoriented firms to enjoy more benefits from trade openness. Thus, a better contribution of trade to economic growth requires taking into account the interrelationship and the complementarity between financial development and trade openness. This finding supports the complementarity hypothesis and corroborates the findings that Herwartz and Walle (2014) and Polat et al. (2015) made. However, this finding suggests that trade openness must be accompanied by complementary policies aimed at encouraging the financing of new investment and enhancing the quality of institutions and the ability to adjust and learn new skills. These policies would then allow resources to be reallocated away from less productive activities and toward more promising ones.

Most of the results regarding the other explanatory variables also conform to the expectations. Initial GDP per capita has a negative coefficient, which is consistent with conditional convergence between countries. Private investment and human capital have positive and statistically significant coefficients, indicating that greater private investment and more highly-educated work force increase economic growth. Regarding macroeconomic stability, inflation and government size have the expected signs, but only the first is statistically significant.

The Index of Economic Freedom is included in the model in order to explain the impact of institutional quality on economic growth. It takes a positive sign and is statistically significant at conventional levels, considering that economic growth is stronger when economic freedom is high because it makes investment more productive. This finding is consistent with the survey conducted by Azman-Saini et al. (2010) who concluded that economic freedom is an important factor for economic growth.

\section{Conclusion}

This paper examines the link between trade openness and GDP growth in the presence of a domestic financial system. Using system GMM panel data model to examine the link between trade openness, financial development and economic growth on a panel of four North African countries, 


\section{Articles}

over a 5-year period from 1998 to 2017, both trade openness and financial development have a significant and positive impact on economic growth.

To examine whether financial development helps a country to benefit more from trade openness, the study related trade openness to financial development variable. The result is that trade openness relates to the financial development indicator; the interaction term is generally positive and significant, shedding light on the role of financial development in benefiting from trade openness.

These findings led to the suggestion that North African countries should complement the trade liberalization process with higher levels of financial development by opening multinational banks and other institution should be promoted to strength financial market in these countries. The financial development will improve economic growth by promoting financial innovation to the private sector. In addition, structural and institutional restriction should be reduced for effective financial system. A well-developed domestic financial system will encourage private players to export more, and it will enhance these countries' foreign reserves. These reserves can be employed to import new technology from developed countries, which promote human capital formation and thus economic growth in these countries.

\section{References}

Acemoglu, D., Johnson, S., and Robinson, J., (2001). "The colonial origins of comparative development: An empirical investigation", American Economic Review, 91, 1369-1401.

Aghion, P., Howitt, P., and Mayer-Foulkes, D., (2005). "The effect of financial development on convergence: Theory and evidence",
Does Financial Development Affect

the Economic Growth Gains from Trade Openness?

Quarterly Journal of Economics, 120(1), 173222.

Alagidede, I.P., Ibrahim, M., and Sare, Y.A., (2020). "Structural transformation in the presence of trade and financial integration in sub-Saharan Africa", Central Bank Review, 20, 21-31.

Almeida, R., and Fernandes, A.M., (2008). "Openness and technological innovations in developing countries: Evidence from FirmLevel Surveys", The Journal of Development Studies, 44, 701-727.

Arellano, M., and Bond, S., (1991). "Some tests of specification for panel data: Monte Carlo evidence and an application to employment equations", Review of Economic Studies, 58(2), 277-297.

Arellano, M., and Bover, O., (1995). "Another look at the instrumental variable estimation of error-component models", Journal of Econometrics, 68(1), 29-51.

Azman-Saini, W.N.W., Law, S.H., and Ahmad, A.H. (2010). "FDI and economic growth: New evidence on the role of financial markets", Economics Letters, 107(2), 211-213.

Baltagi, B. H. (2008). Econometric analysis of panel data. New York: John Wiley \& Sons Ltd., Chichester.

Barro, R.J., and Sala-i-Martin, X., (1997). "Technological diffusion, convergence, and growth." Journal of Economic Growth, 2(1), 1-27.

Beck, T., (2002). "Financial development and international trade: is there a link?", Journal of International Economics, 57(1), 107-131. 


\section{Articles}

Beck, T., Levine, R., and Loayza, N., (2000). "Finance and the sources of growth", Journal of Financial Economics, 58, 261-300

Benhabib, J., and Spiegel, M., (2005). Human Capital and Technology Diffusion. In: Aghion, P., Durlauf, S.N. (Eds.), Handbook of Economic Growth. Elsevier, Amsterdam.

Blackburn, K., and Hung, V.T.Y., (1998). "A theory of growth, financial development and trade", Economica, 65(257), 107-124.

Blundell, R., and Bond, S., (1998). "Initial conditions and moment restrictions in dynamic panel data models", Journal of Econometrics, 87, 115-143.

Bond, E.W., Jones, R.W., and Ping, W., (2005). "Economic takeoffs in a dynamic process of globalization", Review of International Economics, 13(1), 1-19.

Buera, F., Kaoshki, J., and Shin, Y., (2011). "Finance and development: A tale of two sectors." American Economic Review, 101(5), 1964-2002.

Calderon, C., and Liu, L., (2003), "The direction of causality between financial development and economic growth," Journal of Development Economics, 72, 321-334.

Chang, C., and Mendy, M., (2012). "Economic growth and openness in Africa: What is the empirical relationship?", Applied Economics Letters ,19(18), 1903-1907.

Chang, R., Kaltani, L., and Loayza, N.V., (2009). "Openness can be good for growth: The role of policy complementarities", Journal of Development Economics, 90, 33-49.

De Haan, J., (2007), "Political institutions and economic growth reconsidered", Public Choice, 127, 281-292.
Dufrenot, G., Mignon, V., and Tsangarides, C., (2010). "The trade-growth nexus in the developing countries: A quantile regression approach", Review of World Economics, 146, 731-761.

Economidou, C., and Murshid, A.P., (2008). "Testing the linkages between trade and productivity growth", Review of Development Economics, 12, 845-860.

Ehigiamusoe, K., and Lean, H.H., (2018). "Tripartite Analysis of Financial Development, Trade Openness and Economic Growth: Evidence from Ghana, Nigeria and South Africa", Contemporary Economics, 12(2), 189206.

Elder, J., (2004). "Another perspective on the effects of inflation uncertainty", Journal of Money, Credit, and Banking, 36, 911-928.

Fung, H.K., (2009). "Financial development and economic growth: Convergence or divergence?", Journal of International Money and Finance, 28, 56-78.

Glaeser, E., La Porta, R., Lopez-de-Silanes, F., and Shleifer, A., (2004), "Do institutions cause growth?", Journal of Economic Growth, 9, 271-303.

Gries, T., Kraft, M., and Meierrieks, D., (2009). "Linkages between financial deepening, trade openness, and economic development: Causality evidence from Sub-Saharan Africa", World Development, 37(12), 1849-1860.

Grossman, G., and Helpman, E., (1991). "Quality ladders in the theory of growth", Review of Economic Studies, 58(1), 43-61.

Gwartney, J., Lawson, R., Hall, J., and Murphy, R., (2019). Economic Freedom of the World-2019, Annual Report. Fraser Institute. 


\section{Articles}

Herwartz, H., and Walle, Y.M., (2014). "Determinants of the link between financial and economic development: Evidence from a functional coefficient model", Economic Modelling, 37, 417-427.

Hur, J., Raj, M., and Riyanto, Y.E., (2006). "Finance and trade: A cross- country empirical analysis on the impact of financial development and asset tangibility on international trade", World Development, 34(10), 1728-1741.

Jin, J.C., (2000). "Openness and growth: an interpretation of empirical evidence from East Asian countries", Journal of International Trade and Economic Development, 9(1), 5-17. Kim, D.H., Lin, S.C., and Suen, Y.B., (2010). "Are financial development and trade openness complements or substitutes?", Southern Economic Journal, 76 (3), 827-845.

Kim, D.H., Lin, S.C., and Suen, Y.B., (2012). "The simultaneous evolution of economic growth, financial development, and trade openness", The Journal of International Trade and Economic Development, 21(4), 513-537.

King, R.G., and Levine, R., (1993), "Finance and growth: Schumpeter might be right", Quarterly Journal of Economics, 108(3), 717737.

Kpomblekou, E.K.M., and Wonyra, K.O., (2020). "Spatial diffusion of international trade in West African Economic and Monetary Union (WAEMU)", Scientific African, 7, e00295.

Lee, L.F., (2007). "GMM and 2SLS estimation of mixed regressive, spatial autoregressive models", Journal of Econometrics, 137, 489514.

Levine, R., (2005). In: Aghion, P. and Durlauf, S.N. (Eds.), Finance and growth: theory,
Does Financial Development Affect

the Economic Growth Gains from Trade Openness?

mechanism and evidence, Handbook of Economic Growth, 1, 865-934.

Levine, R., Loayza, N., and Beck, T., (2000). "Financial intermediation and growth: Causality and causes", Journal of Monetary Economics, 46(1), 31-77.

Lin, X., and Lee, L.F., (2010). "GMM estimation of spatial autoregressive models with unknown heteroskedasticity", Journal of Econometrics, 157, 34-52.

Mankiw, N.G., Romer., D., and Weil, D., (1992). "A contribution to the empirics of economic growth", Quarterly Journal of Economics, 107, 407-437.

Mohamed Sghaier, I., (2018), "Foreign direct investment, financial development and economic growth in North African countries", Economic Alternatives, 4, 527-540.

Nguyen, C.T., and Trinh, L.T., (2018). "The impacts of public investment on private investment and economic growth Evidence from Vietnam", Journal of Asian Business and Economic Studies, 25(1), 15-32.

Nickell, S., (1981). "Biases in dynamic models with fixed effects", Econometrica, 49, 14171426.

Niroomand, F., Hajilee, M., and Al Nasser, O., (2014). "Financial market development and trade openness: Evidence from emerging economies", Applied Economics, 46(13), 1490-1498.

Peters, K., and Schnitzer, M., (2012). "Trade liberalization and credit constraints: Why opening up may fail to promote convergence", CEPR Discussion Paper, 8942.

Polat, A., Shahbaz, M., Rehman, I.U., and Satti, S.L., (2015). "Revisiting linkages 


\section{Articles}

between financial development, trade openness and economic growth in South Africa: fresh evidence from combined cointegration test", Quality and Quantity, 49(2), 785-803.

Pradhan, R.P., Arvin, M.B., Hall, J.H., and Norman,N.R., (2017). "ASEAN economic growth, trade openness and banking-sector depth: The nexus", Economia, 18, 359-379.

Rajan, R.G., and Zingales, L., (1998). "Financial dependence and growth", American Economic Review, 88, 559-586.

Rajan, R.G., and Zingales, L., (2003). "The great reversals: the politics of financial development in the twentieth century", Journal of Financial Economics, 69(1), 5-50.

Ramírez-Rondán,N.R., Terrones, E.T., and Vilchez, A., (2018). "Does financial sector development affect the growth gains from trade openness?", MPRA Paper n 90385.

Rani, R., and Kumar, N., (2018). "Panel data analysis of financial development, trade openness, and economic growth: Evidence from BRICS countries", Emerging Economy Studies, 4(1), 1-18.

Rassekh, F., (2007). "Is international trade more beneficial to lower income economies? An empirical inquiry", Review of Development Economics, 11, 159-169.

Redmond, T., and Ali Nasir, M., (2020). "Role of natural resource abundance, international trade and financial development in the economic development of selected countries", Resources Policy, 66, 101591.

Rivera-Batiz, L.A., and Romer, P.M., (1991). "Economic integration and endogenous growth", Quarterly Journal of Economics, 106, 531-555.
Romer, P., (1990). "Endogenous technological change", Journal of Political Economy, 98(5), 71-102.

Roodman, D., (2006). "How To Do xtabond2: An Introduction to Difference and System GMM in Stata", Center for Global Development Working Paper, n'103.

Sakyi, D., Villaverde, J., and Maza, A., (2017). "The effects of trade and trade facilitation on economic growth in Africa", African Development Review, 29(2), 350-361.

Santos-Paulino, A., and Thirlwall, A.P., (2004). "Trade liberalization and economic performance in developing countries", The Economic Journal, 114(493), 1-3.

Sare, Y.A., Aboagye, A.Q.Q., Mensah, L., and Bokpin, G.A., (2018). "Effect of financial development on international trade in Africa: Does measure of finance matter?", The Journal of International Trade and Economic Development, 27(8), 917-936.

Sare, Y.A., (2019). "Threshold Effects of Financial Sector Development on International Trade in Africa", International Journal of Finance and Economics, First published: 13 November 2019.

Stanojević, J., and Veličković, G., (2019). "The Role of EU Accession in Economic Development from the International Trade Perspective", Economic Alternatives, 3, 412428.

Susanto, D., Rosson, C.P., and Costa, R., (2011). "Financial development and international trade: Regional and sectoral analysis", Agricultural and Applied Economics Association \& NAREA joint annual meeting Pittsburgh, Pennsylvania, July 24-26. 


\section{Articles}

Svaleryd, H., and Vlachos, J., (2002). "Markets for risk and openness to trade: How they are related", Journal of International Economics, 57(2), 369-395.

Svaleryd, H., and Vlachos, J., (2005). "Financial markets, the pattern of industrial specialization and comparative advantage: Evidence from OECD countries", European Economic Review, 49(1), 113-144.

Windmeijer, F., (2005). "A finite sample correction for the variance of linear efficient two-step GMM estimators", Journal of Econometrics, 126, 25-51.

Wolde-Rufael, Y., (2009). "Re-examining the financial development and economic growth nexus in Kenya", Economic Modelling, 26(6), 1140-1146.
Does Financial Development Affect

the Economic Growth Gains from Trade Openness?

World Bank (2020), World Development Indicators, World Bank, Washington DC.

Yanikkaya, H., (2003). "Trade openness and economic growth: A cross country empirical investigation", Journal of Development Economics, 72(1), 57-89.

Yilmazkuday, H., (2011). "Thresholds in the finance-growth nexus: A cross-country analysis", World Bank Economic Review, 25 (2), 278-295.

Zahonogo, P., (2016). "Trade and economic growth in developing countries: Evidence from Sub Saharan Africa", Journal of African Trade, 3(1-2), 41-56.

Zouri, S., (2020). "Business cycles, bilateral trade and financial integration: Evidence from Economic Community of West African States", International Economics, 163, 25-43. 